\title{
Characterization of a novel Lactobacillus species closely related to Lactobacillus johnsonii using a combination of molecular and comparative genomics methods
}

Luz-Adriana Sarmiento-Rubiano ${ }^{1}$, Bernard Berger², Déborah Moine², Manuel Zúñiga', Gaspar Pérez-Martínez ${ }^{1}$, María J Yebra ${ }^{*}$

\begin{abstract}
Background: Comparative genomic hybridization (CGH) constitutes a powerful tool for identification and characterization of bacterial strains. In this study we have applied this technique for the characterization of a number of Lactobacillus strains isolated from the intestinal content of rats fed with a diet supplemented with sorbitol.
\end{abstract}

Results: Phylogenetic analysis based on 165 rRNA gene, recA, pheS, pyrG and tuf sequences identified five bacterial strains isolated from the intestinal content of rats as belonging to the recently described Lactobacillus taiwanensis species. DNA-DNA hybridization experiments confirmed that these five strains are distinct but closely related to Lactobacillus johnsonii and Lactobacillus gasseri. A whole genome DNA microarray designed for the probiotic L. johnsonii strain NCC533 was used for CGH analysis of L. johnsonii ATCC 33200', L. johnsonii BL261, L. gasseri ATCC $33323^{\top}$ and L. taiwanensis BL263. In these experiments, the fluorescence ratio distributions obtained with L. taiwanensis and L. gasseri showed characteristic inter-species profiles. The percentage of conserved L. johnsonii NCC533 genes was about $83 \%$ in the L. johnsonii strains comparisons and decreased to $51 \%$ and $47 \%$ for $L$. taiwanensis and $L$. gasseri, respectively. These results confirmed the separate status of $L$. taiwanensis from $L$. johnsonii at the level of species, and also that L. taiwanensis is closer to L. johnsonii than L. gasseri is to L. johnsonii.

Conclusion: Conventional taxonomic analyses and microarray-based CGH analysis have been used for the identification and characterization of the newly species L. taiwanensis. The microarray-based CGH technology has been shown as a remarkable tool for the identification and fine discrimination between phylogenetically close species, and additionally provided insight into the adaptation of the strain L. taiwanensis BL263 to its ecological niche.

\section{Background}

A number of species belonging to the genus Lactobacillus are indigenous to the gastrointestinal tract of humans and animals [1-3]. Due to their ecological and commercial interest, substantial efforts have been concentrated in the past years to isolate and identify new strains of lactobacilli. Many of those strains belong to the Lactobacillus acidophilus complex. The first major

\footnotetext{
* Correspondence: yebra@iata.csic.es

'Laboratorio de Bacterias Lácticas y Probióticos. IATA-CSIC, P.O. Box 73,

46100 Burjassot, Valencia, Spain

Full list of author information is available at the end of the article
}

study on this group using DNA-DNA hybridization defined two main homology groups, A and B, with six subgroups [4], that later became distinct species [5]. Strains of the group A were classified as the species L. acidophilus, Lactobacillus amylovorus, Lactobacillus crispatus and Lactobacillus gallinarum, and strains of the group B became Lactobacillus gasseri and Lactobacillus johnsonii [5]. Some strains of L. acidophilus and $L$. johnsonii are commercialized as probiotics and they have been subjected to extensive studies aimed to infer the mechanisms governing their beneficial health effects. L. acidophilus strain NCFM increased the 
immunogenicity of an oral human rotavirus vaccine in animals [6]. L. acidophilus strain Bar13 interfered with the adhesion of enteropathogenic bacteria to enterocytes and inhibited IL- 8 production by HT-29 cells, suggesting a potential to protect intestinal cells from acute inflammatory response [7]. L. johnsonii strain La1 (NCC533) has been shown to suppress gene expression of proinflammatory cytokines, supposedly involved in atopic dermatitis [8,9] and acts as an immunomodulator [10-12]. The genome of L. johnsonii strain NCC533 has been sequenced [13] and has enabled a number of studies aimed to determine the genes which are expressed in vivo and those whose expression is specifically necessary for long persistence in the gut $[14,15]$.

The bacterial species concept has been widely discussed $[16,17]$, but no consensus has been reached to establish a regularly acceptable definition. In the case of prokaryotic pathogens, species are traditionally identified on the basis of the disease they caused, regardless of genetic considerations. However, for the vast majority of bacteria, phenotypic characteristics are generally not as precise as identification based on genotypic methods. The observation that there are a fraction of genes found in bacterial genomes shared by all members of a species and a fraction present only in a subset of the population gave rise to the core genomic hypothesis [18]. It postulates that there is a core of genes responsible for keeping a species identity and auxiliary genes responsible for gene transfer and adaptation of strains to the environment. The incorporation of molecular data permitted to state that a bacterial species is "a category that circumscribes a (preferably) genomically coherent group of individual isolates/strains sharing a high degree of similarity in (many) independent features, comparatively tested under highly standardised conditions" [19]. Essentially, a species would be a group of strains with certain level of phenotypic consistency and showing DNA-DNA re-association rates greater than 70\% [19]. However, this variability cut-off method is not always appropriate due to the fact that different clearly recognized species have a large range of genetic variation. Since DNA sequencing is nowadays an accessible technique to most laboratories, comparative sequence analysis of the $16 \mathrm{~S}$ rRNA gene has been extensively used for species identification in novel isolates [20]. The ad hoc committee for the re-evaluation of the species definition in bacteriology considered sequencing of housekeeping genes, DNA profiling and DNA arrays as very valuable methods for species delineation and phylogenetic positioning [19].

The L. acidophilus group constitutes a paradigm of a compact cluster showing closely related species that offers special difficulties for the correct taxonomic allocation of new strains. Several techniques have been applied to identify members of the L. acidophilus group, such as 23S-rRNA-targeted oligonucleotide probe hybridization [21], random amplification of polymorphic DNA [22,23], sequence alignment of the V1 region of the $16 \mathrm{~S}$ rRNA encoding gene [24] and automated ribotyping [25]. Recently, more complex genomic techniques based on multilocus sequence analysis of five housekeeping genes and comparative genome hybridization $(\mathrm{CGH})$ using microarrays have been successfully applied to the L. acidophilus complex [26]. They showed that $L$. johnsonii, L. gasseri and L. acidophilus constitute three clearly independent and consistent genomic groups, although $L$. gasseri was more closely related to L. johnsonii than to L. acidophilus. The bacterial genomic variability between strains belonging to the same species or between closely related species comes from mobile DNA elements and from variable regions. The latest may be required for environmental adaptation and could be acquired by lateral gene transfer. The L. johnsonii NCC533 chromosome harbors three regions that contain two prophages, Lj928 and Lj965, and a 6-kb potentially autonomous unit $[27,28]$. These genetic elements represent more than half of the identified strainspecific DNA and have been extensively studied [26-28]. L. johnsonii NCC533 also carries four further integrases and several IS elements flanking or disrupting diversity regions [26-28].

A previous work studying the influence of sorbitol intake on the population of rat intestinal lactobacilli showed the presence of five species: L. johnsonii, Lactobacillus intestinalis, Lactobacillus murinus, Lactobacillus reuteri and Lactobacillus sp. BL263 (previously named as AD102) [29]. Sorbitol ingestion resulted in an increment of L. reuteri and Lactobacillus sp. BL263 cell numbers [29]. Although strain Lactobacillus sp. BL263 could be assigned to the $L$. acidophilus group, its species allocation was still uncertain. In the present study, standard taxonomic methods and microarray-based CGH analysis have been implemented for the identification and characterization of Lactobacillus sp. BL263 and four additional rat intestinal isolates (BL301, BL302, BL303 and BL304) displaying identical PCR-DGGE pattern.

\section{Methods}

Bacterial strains, culture conditions, DNA extraction

The Lactobacillus strains used in this work are listed in Table 1 and they were grown in MRS medium (Difco) at $37^{\circ} \mathrm{C}$ during $48 \mathrm{~h}$ under static conditions. Chromosomal DNA was isolated as described before [30].

\section{S rRNA encoding gene and multilocus sequence analyses}

The housekeeping genes selected for multilocus sequence analysis based on the results of previous studies on Lactobacillus species [26,31] were recombinase 
Table 1 List of strains used in this study

\begin{tabular}{|c|c|c|c|}
\hline Species & Strain $^{a}$ & $\begin{array}{l}\text { Culture } \\
\text { collection }^{\mathrm{b}}\end{array}$ & Host \\
\hline $\begin{array}{l}\text { Lactobacillus } \\
\text { acidophilus }\end{array}$ & BL17 & CECT $903^{\top}$ & human \\
\hline $\begin{array}{l}\text { Lactobacillus } \\
\text { acidophilus }\end{array}$ & BL279 & CECT 4529 & $\begin{array}{l}\text { chicken } \\
\text { intestine }\end{array}$ \\
\hline $\begin{array}{l}\text { Lactobacillus } \\
\text { acidophilus }\end{array}$ & BL280 & CECT 4179 & rat feces \\
\hline Lactobacillus crispatus & BL221 & & human feces \\
\hline Lactobacillus crispatus & BL278 & DSMZ $20584^{\top}$ & human eye \\
\hline Lactobacillus gasseri & BL223 & & human feces \\
\hline Lactobacillus gasseri & BL277 & ATCC $33323^{\top}$ & human \\
\hline Lactobacillus gasseri & BL292 & NCC 2858 & unknown \\
\hline Lactobacillus gasseri & BL294 & NCC 2856 & unknown \\
\hline Lactobacillus gasseri & BL296 & NCC 2857 & unknown \\
\hline Lactobacillus intestinalis & BL260 & & rat intestine \\
\hline Lactobacillus intestinalis & BL288 & DSMZ $6629^{\top}$ & rat intestine \\
\hline Lactobacillus johnsonii & BL261 & & rat intestine \\
\hline Lactobacillus johnsonii & BL281 & CECT 289 & unknown \\
\hline Lactobacillus johnsonii & BL287 & ATCC $33200^{\top}$ & human blood \\
\hline Lactobacillus johnsonii & BL295 & NCC 2822 & dog feces \\
\hline Lactobacillus johnsonii & BL297 & NCC 1741 & unknown \\
\hline Lactobacillus johnsonii & BL298 & NCC 533 & human feces \\
\hline Lactobacillus johnsonii & BL299 & NCC 2767 & dog feces \\
\hline Lactobacillus murinus & BL262 & & rat intestine \\
\hline Lactobacillus reuteri & BL259 & & rat intestine \\
\hline $\begin{array}{l}\text { Lactobacillus } \\
\text { taiwanensis }\end{array}$ & BL263 & CECT 7394 & rat intestine \\
\hline $\begin{array}{l}\text { Lactobacillus } \\
\text { taiwanensis }\end{array}$ & BL301 & & rat intestine \\
\hline $\begin{array}{l}\text { Lactobacillus } \\
\text { taiwanensis }\end{array}$ & BL302 & & rat intestine \\
\hline $\begin{array}{l}\text { Lactobacillus } \\
\text { taiwanensis }\end{array}$ & BL303 & & rat intestine \\
\hline $\begin{array}{l}\text { Lactobacillus } \\
\text { taiwanensis }\end{array}$ & BL304 & & rat intestine \\
\hline $\begin{array}{l}\text { Lactobacillus } \\
\text { taiwanensis }\end{array}$ & BL340 & DSMZ $21401^{\top}$ & silage \\
\hline
\end{tabular}

${ }^{\mathrm{a} B L}$, Culture Collection from our laboratory. Strains BL263, BL260, BL261, BL262 and BL259 were previously named as AD102, AD38, AD99, AD100 and AD23, respectively [29].

${ }^{b} \mathrm{CECT}$, The Spanish Type Culture Collection; DSMZ, German Collection of Microorganisms and Cell Cultures; NCC, Nestlé Culture Collection; ATCC, American Type Culture Collection.

A $(\operatorname{rec} A)$, phenylalanyl-tRNA synthase (pheS), CTP synthetase $(p y r G)$ and translational elongation factor $\mathrm{Tu}$ (tuf). PCR reactions were performed with the Expand High Fidelity PCR System (Roche), using chromosomal DNA and the primers listed in Table 2. DNA sequencing was performed by the Central Service of Research Support of the University of Valencia (Spain) by using the Dideoxynucleotide DNA chain termination method. Both strands of the PCR fragments were sequenced. In the case of the recA gene, the PCR fragments were cloned in Escherichia coli using the pMOS Blue vector contained in the Blunt- ended cloning kit (GE Healthcare) following the manufacturer instructions. Plasmid DNA was isolated from each clone containing a portion of the recA gene from the Lactobacillus strains studied here. The partial $r e c A$ genes were sequenced using the M13 universal and reverse primers.

\section{Phylogenetic analysis}

The sequences were either obtained in this work, retrieved from the GenBank database or from the Ribosomal Database Project II (RDP) [32]. Multiple alignments were obtained using ClustalX [33]. Positions of doubtful homology and gaps were removed by using Gblocks [34]. The phylogenetic reconstruction was performed by maximum likelihood as implemented in PHYML [35] with the GTR, substitution model in combination with estimation of the transtition/transversion ratio by maximizing the likelihood of the phylogeny, and estimations from the data set of the proportion of invariants and the shape parameter (alpha) of the gamma distribution to account for substitution rate heterogeneity among sites. Bootstrap support values were obtained through the analysis of 500 pseudoreplicates.

\section{Physiological characterization}

Carbohydrate fermentation patterns were determined by using the API $50 \mathrm{CH}$ (BioMérieux, S.A.) according to the supplier instructions. Results were recorded after 48 $\mathrm{h}$ at $37^{\circ} \mathrm{C}$. Growth at $15^{\circ} \mathrm{C}, 45^{\circ} \mathrm{C}, \mathrm{pH} 4.5$ or in the presence of $\mathrm{NaCl}$ (4.5\% and 7.0\%) was determined in MRS broth (Difco). All the growth analyses were done at least in duplicate. Data were analysed using Pearson's correlation coefficient (XLSTAT programme). A tree was created by cluster analysis using the unweighted pair-group method with arithmetic averages (UPGMA).

\section{PAGE analysis of whole-cell protein}

Cultures were grown in $10 \mathrm{ml}$ MRS at $37^{\circ} \mathrm{C}$ to an $\mathrm{OD}_{550}$ of 1.0. Cells were collected by centrifugation, washed with Tris- $\mathrm{HCl} 100 \mathrm{mM}, \mathrm{pH}$ 7.5, resuspended in $1 \mathrm{ml}$ of the same buffer plus sucrose $0.5 \mathrm{M}$ and lysozyme $2.5 \mathrm{mg} / \mathrm{ml}$. After incubation for $1 \mathrm{~h}$ at $37^{\circ} \mathrm{C}$, cells were washed, collected by centrifugation and resuspended in $50 \mu \mathrm{l}$ of SDS-PAGE loading buffer. Cells were lysed at $100^{\circ} \mathrm{C} 5 \mathrm{~min}$ and $20 \mu \mathrm{l}$ of total extract were separated on a $12 \%$ SDS-PAGE using standard protocols [36]. The gels were stained with Coomassie brilliant blue. For each strain among two and four independent extracts were performed and analysed by SDSPAGE. A PAGE analysis representative of each strain is shown in the results. Data were analysed using Pearson's correlation coefficient (BioNumerics 4.6 Applied Maths Kortrijk). A tree was created by cluster analysis using UPGMA. 
Table 2 Multilocus sequence analysis

\begin{tabular}{|c|c|c|c|c|}
\hline Gene & Primer & Nucleotide sequence & $\begin{array}{l}\text { Amplified fragment } \\
\text { size (bp) }\end{array}$ & $\begin{array}{l}\text { Number of alleles in } \\
\text { L. taiwanensis strains }\end{array}$ \\
\hline \multirow[t]{2}{*}{$16 \mathrm{~S}$ rRNA } & $165-27$ for & 5'-AGAGTTTGATCCTGGCTCAG & 1552 & 1 \\
\hline & 16S-1552rev & 5'-AAGGAGGTGWTCARCCGCA & & \\
\hline \multirow[t]{2}{*}{ recA } & RecAfor & 5'-GAAAARRAYTTYGGWAARGGYKCDRTBATGCG & 740 & 0 \\
\hline & RecArev & 5'-TACATRATRTCDACTTCWSMNMSYTTRAATGG & & \\
\hline \multirow[t]{2}{*}{ phes } & PheSfor & 5'-KGGDCGYAAGGGTGAATTAAC & 908 & 0 \\
\hline & PheSrev & 5'-ACATCRTTWGTRTAGAARTCACGAATATC & & \\
\hline \multirow[t]{2}{*}{ tuff } & Tuf-for & 5'-ATGGCAGAAAAAGAACATTACG & 1176 & 1 \\
\hline & Tuf-rev & 5'-AGTAACYTGACCRGCACCAAC & & \\
\hline \multirow[t]{2}{*}{ pyrG } & PyrGfor & 5'-TTATGTTACYGAYGATGGTAC & 908 & 0 \\
\hline & PyrGrev & 5'-ACCACGWGTACCAAAACCAC & & \\
\hline
\end{tabular}

\section{DNA-DNA hybridization assays}

DNA macro-arrays on nylon membranes (Hybond $\mathrm{N}$, Amersham Biosciences) were performed by using a dot blot assay according to Hänninen et al. [37] with some modifications. Three aliquots (160, 80 and $40 \mathrm{ng}$ ) of denatured chromosomal DNA samples of 26 Lactobacillus strains were spotted on duplicated membranes. Six digoxigenin-labelled probes were prepared by random priming using the DIG DNA Labelling kit (Roche) and genomic DNA isolated from the type strains of $L$. intestinalis, L. johnsonii, L. crispatus, L. gasseri, L. acidophilus or L. taiwanensis. Those probes were hybridized against six identical macroarrays with 26 Lactobacillus strains. Hybridization, washing and staining was carried out as recommended by the manufacturer using the CDP-Star chemiluminescent substrate (Roche). Chemiluminescence was detected in a Fujifilm LAS 1000 imaging system (Fuji Photo Film Co. Ltd.) and it was measured using the Image Gauge Version 4.0 programme. The DNA-DNA hybridization experiments were done in triplicate.

\section{Comparative genomic hybridization on microarrays}

Based on the genome sequence of L. johnsonii NCC533 [13], Agilent 60-mer oligo microarrays were designed with 5 to 6 probes spreading the coding sequence of each gene (Agilent technologies Inc., USA). Genomic DNA was prepared and labelled as previously described [26]. Hybridization reactions were performed in a volume of $210 \mu \mathrm{l}$ with $10 \mu \mathrm{l}$ of labelled DNA, 70 $\mu \mathrm{l}$ of nuclease free water, $25 \mu \mathrm{l}$ of control target Agilent and $105 \mu \mathrm{l}$ of Agilent hybridization buffer, following the recommendations of the manufacturer. The slides were washed $10 \mathrm{~min}$ at RT in $6 \times \mathrm{SSC}, 0.005 \%$ Triton $\mathrm{x}-100$ and $10 \mathrm{~min}$ on ice in $0.1 \times \mathrm{SSC}, 0.005 \%$
Triton $x-100$. The slides were immediately dried by centrifugation and scanned at $10 \mu \mathrm{m}$ with a Scanarray 4000 (Packard Biochip Technologies, Billerica, MA, USA). Data were extracted with Imagene 5.6 (Biodiscovery, El Segundo, CA, USA) and treated with homemade scripts in Python language http://www.python. org. Probes were eliminated from the analysis if their signal strength was lower than twice the standard deviation of the local background when hybridized with L. johnsonii NCC533 genomic DNA. The signal ratio (Cy3-labeled unknown strain DNA versus Cy5labeled L. johnsonii NCC533 DNA) of each spot was calculated without background subtraction and normalized based on our previous experience of CGH [26]. Having 5 to 6 probes per gene, each gene signal ratio was given by the median of the corresponding probes values. Considering the low level of strain variability for the tested molecule (DNA), the large number of probes per gene and the robustness of the median, biological replicates of hybridizations focused only on the most critical analysis: self-NCC533 (validation of the arrays), ATCC $33200^{\mathrm{T}} / \mathrm{NCC} 533$ (intra-species comparison), and BL263/NCC533 (inter-species comparison with the novel Lactobacillus).

\section{Accession numbers}

The 16S rRNA gene, recA, pheS, tuf and pyrG sequences generated in this study were deposited in the GenBank under accession numbers FJ556999 to FJ557013, FJ557014 to FJ557023, GU121623 to GU121628 and HM777006, GU121629 to GU121634 and HM777008, and GU121635 to 121640 and HM777007, respectively. The microarrays data have been deposited in NCBI's Gene Expression Omnibus [38] and are accessible through GEO Series accession number GSE21627. 


\section{Results}

$16 \mathrm{~S}$ rRNA encoding gene and multilocus sequence analyses positioned the novel Lactobacillus isolates within the Lactobacillus acidophilus group

Sequences of the $16 \mathrm{~S}$ rRNA gene (approximately 1,440 bp) of the rat isolates Lactobacillus sp. BL263, BL301, BL302, BL303 and BL304 were determined. Sequences of BL263, BL301, BL302 and BL303 were identical (data not shown) and shared a $99.9 \%$ sequence identity with BL304 strain. A preliminary analysis showed that these sequences were very similar to sequences of L. gasseri and $L$. johnsonii. Subsequently, a phylogenetic tree was obtained by using the tools available in RDP [32]. On the basis of this reconstruction, sequences of species close to L. gasseri and L. johnsonii were selected for a detailed phylogenetic reconstruction by maximum likelihood. During the preparation of this manuscript, the novel L. taiwanensis species isolated from silage was described [39]. The phylogenetic reconstruction based on $16 \mathrm{~S}$ rRNA gene sequences suggested that these strains belong to L. taiwanensis species and that they are closely related to L. johnsonii and L. gasseri (Fig. 1). The identity between the 16S rRNA gene of L. taiwanensis and L. johnsonii and L. gasseri strains ranged from $99.2 \%$ to $99.7 \%$ and $98.5 \%$ to $99.5 \%$, respectively. This is higher than the generally accepted $>97 \%$ identity threshold for the species definition, but this problem is known for long in the acidophilus group [24].

The analysis of the $\operatorname{rec} A$, pheS, pyrG and tuf gene sequences from strains BL263, BL301, BL302, BL303, BL304 and L. taiwanensis DSM $21401^{\mathrm{T}}$ also led to phylogenetic trees that clearly separated a cluster encompassing $L$. taiwanensis and the rat intestinal isolates from all the L. johnsonii and L. gasseri strains as indicated by the bootstrap values (Fig. 2 and Fig. 3). Therefore, we concluded that our isolates belong to $L$. taiwanensis. These phylogenetic reconstructions were in general agreement with that obtained with the $16 \mathrm{~S}$ rRNA gene sequences described above. Although highly conserved, those genes showed a higher degree of variability between related bacteria than the $16 \mathrm{~S}$ rRNA gene. Therefore, the multilocus sequence analysis provided higher discriminating power which is more suited for phylogenetic and taxonomic reconstruction within the closely related species that constitute the L. acidophilus group.

\section{Phenotypic and protein profile analyses did not resolve species}

The carbohydrate fermentation patterns, and the growth profiles of 26 lactobacilli (including the novel isolates and members of the L. acidophilus group) at different temperatures and salt concentrations were used to construct a dendrogram (Table 3 and Fig. 4). Similarly, a comparative analysis of whole-cell protein patterns was performed with bacterial protein extracts of the novel isolates and other members of the L. acidophilus group (Fig. 4). Neither the phenotypic dendrogram, nor the cluster analysis of the SDS-PAGE protein profiles showed a good agreement with the phylogenetic relationships inferred from genetic markers. These phenotypic and protein profiles analyses agree with previous taxonomic analyses [40] that showed a lack of correlation between phylogenetic positioning and physiological/ biochemical properties in lactobacilli. Notwithstanding, L. taiwanensis strains grouped together in a subcluster of the phenotypic analysis with an internal similarity above $30 \%$ (Fig. 4).

\section{DNA-DNA hybridization experiments confirmed the} separate status of Lactobacillus taiwanensis strains at the species level

DNA similarity values were determined by DNA-DNA hybridization with 26 Lactobacillus strains. DNA of the 26 strains was immobilized in membrane blots and the genomic DNA of six Lactobacillus type strains and L. taiwanensis BL263 strain was used as probe (Table 4). Relative hybridization values obtained from intra-species hybridization assays with L. intestinalis, L. acidophilus or L. crispatus strains always rendered values above $82 \%$, while inter-species DNA re-association values between those species were low (1\% to $18 \%)$. Results obtained with L. johnsonii, L. gasseri and L. taiwanensis were less clear-cut. L. johnsonii and L. gasseri intra-species hybridization values were greater than 71\%, but L. johnsonii BL261 and L. gasseri BL223 only showed values of $57 \%$ and $62 \%$ with their respective type strains. Nevertheless, those values still fall within relaxed species delineation boundaries (50$70 \%$ DNA reassociation) [20]. L. taiwanensis showed intra-specific hybridization values in the range of $73 \%$ to $95 \%$. Inter-species hybridizations between L. johnsonii and L. gasseri strains rendered values up to $46 \%$, and always higher than with the other species included in this assay, supporting that they are closely related but distinct species. L. taiwanensis strains also showed high reassociation rates with $L$. johnsonii and L. gasseri, their inter-species hybridization values ranging from $21-40 \%$ and from 10-26\%, respectively. Therefore, these results also demonstrated the separate status of L. taiwanensis strains at the species level, and undoubtedly placed them within the L. acidophilus complex. Inside this group they showed closer DNA homology to L. johnsonii and L. gasseri than to L. crispatus and L. acidophilus in agreement with the previous phylogenetic analyses. 


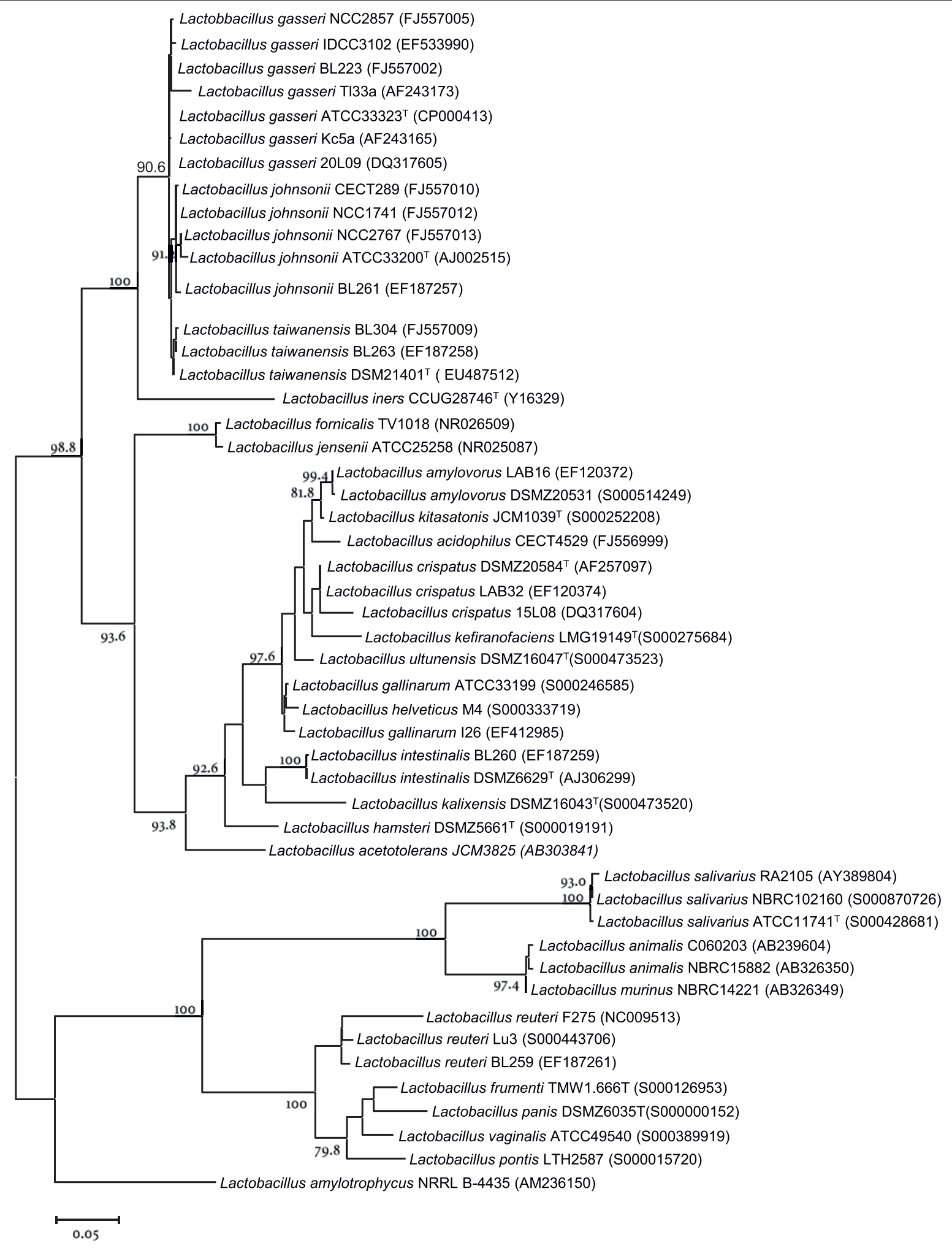

Figure 1 Phylogenetic tree showing relationships among 16S rRNA gene sequences of species in the Lactobacillus acidophilus group, including Lactobacillus taiwanensis, and species representing different lineages within the genus Lactobacillus. The tree was created using a maximum-likelihood approach and numbers at branch points are bootstrap values (based on 500 samplings expressed in percentages). Only bootstrap values over $75 \%$ are shown. Bar indicates sequence divergence. The tree has been arbitrarily rooted. In parenthesis are shown the GenBank or Ribosomal Database Project II accession numbers. 


\section{B}

A

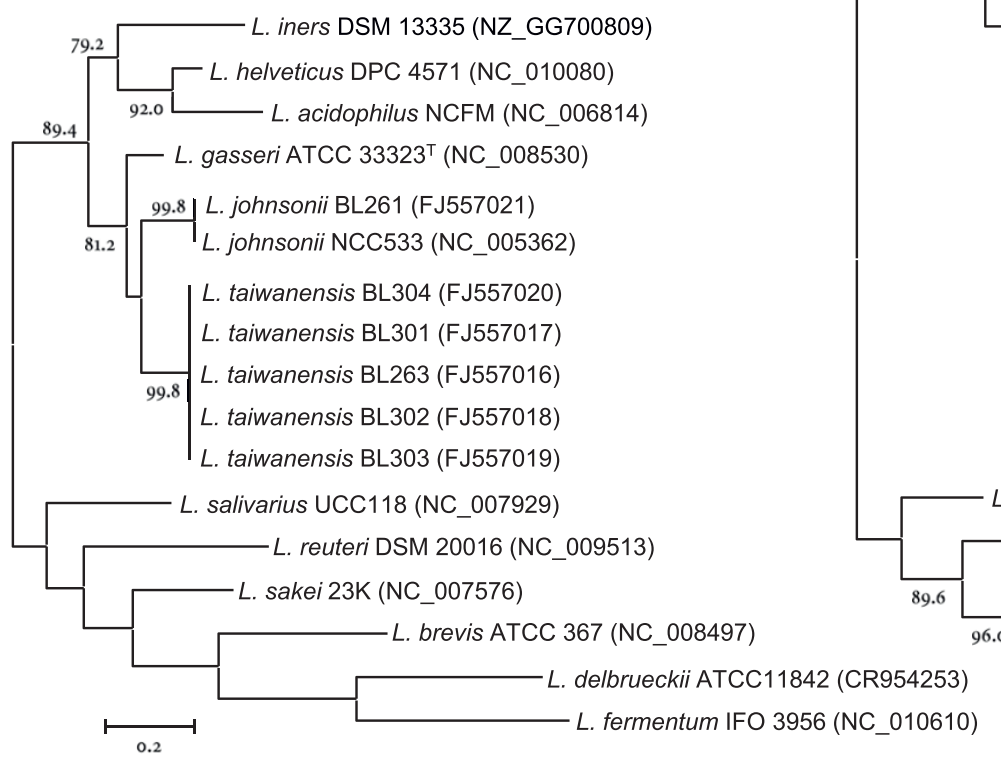

Figure 2 Phylogenetic tree showing relationships among $\operatorname{rec} A(\mathrm{~A})$ and pheS (B) gene sequences of species in the Lactobacillus acidophilus group, including Lactobacillus taiwanensis, and species representing different lineages within the genus Lactobacillus. The trees were created using a maximum-likelihood approach and numbers at branch points are bootstrap values (based on 500 samplings expressed in percentages). Only bootstrap values over 75\% are shown. Bar indicates sequence divergence. The trees have been arbitrarily rooted. In parenthesis are shown the GenBank accession numbers.

Complete Genome Hybridization between L. taiwanensis BL263 and L. johnsonii NCC533 using DNA microarrays Firstly, the DNA microarray constructed with oligonucleotides representing all the coding regions from $L$. johnsonii strain NCC533 was tested in a self-hybridization experiment to validate the design of the microarrays. This step was necessary since the microarrays previously used for inter-species CGH in the L. acidophilus group [26] were amplicon-based and not oligonucleotide-based. Thus, L. johnsonii NCC533 strain was used as both the reference and the test strain, and as expected the distribution of the $\log _{2}$ ratios showed a normal distribution around zero (data not shown). The performance of the oligonucleotide microarray was further evaluated by hybridization with DNA from L. johnsonii ATCC 33200 type strain and L. johnsonii BL261. In the DNA-DNA hybridization assays, this latter strain fell into the relaxed definition of species. The distribution of the $\log _{2}$ ratios of the $\mathrm{CGH}$ results are shown in Fig. 5A. Approximately $83 \%$ of the ORFs present in NCC533 strain produced a $\log _{2}$ ratio of -3.5 or greater with these two strains, suggesting a majority of very similar DNA sequences. The rest of ORFs showed $\log _{2}$ values under -3.5 , reflecting high divergence or absent genes in the test strains. The two L. johnsonii strains profiles were typical of intra-species comparisons. In contrast, L. taiwanensis and $L$. gasseri strains showed a significant deviation from zero for nearly all the genes, suggesting global sequence divergence between L. johnsonii and both tested strains (Fig. 5A). These strains gave a similar profile, characteristic of inter-species comparisons. However, L. taiwanensis have more probes $(51 \%)$ with ratios of -3.5 or greater than $L$. gasseri (47\%), showing slightly better gene conservation. This is in agreement with the results of DNA-DNA hybridization experiments. These results confirmed the separate status of $L$. taiwanensis from $L$. johnsonii at the level of species, and they showed that L. taiwanensis is closer to L. johnsonii than L. gasseri is to L. johnsonii.

$\mathrm{CGH}$ results were mapped on the $L$. johnsonii NCC533 genome (Fig. 5B). The genetic differences observed in the intra-species analysis with the L. johnsonii ATCC 33200 type strain closely match with the previous analysis by amplicon-based microarrays [26], further validating the oligonucleotide-based microarrays used in this study. While L. taiwanensis BL263 shared fewer genes with the reference L. johnsonii NCC533 than the other L. johnsonii strains, it showed 78 genes which are not always present in L. johnsonii strains. They are mainly organized in 6 gene clusters: the sec locus, a hypothetical fimbrial protein, the bacteriocin lactacin F biosynthesis operon, the lactose utilization cluster, the sugar nucleotide dTDP-rhamnose synthesis 


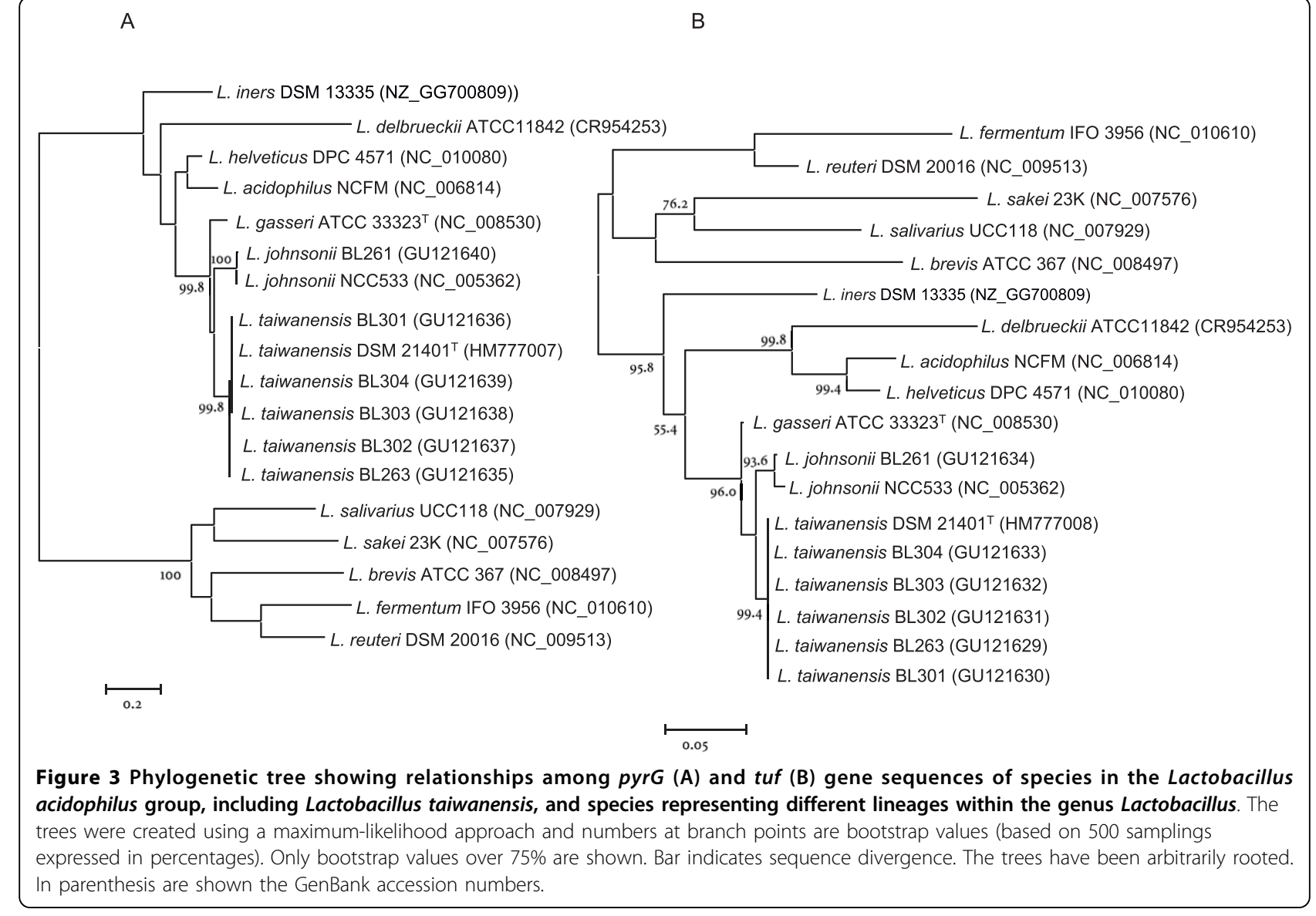

operon and glycosyltransferases (Fig. 5B, marked with an asterisk). Notably, the most similar genes, thus showing the highest $\log _{2}$ ratios $(\geq-0.34)$ for a complete cluster, between $L$. johnsonii and L. taiwanensis form a clear-cut cluster containing an $\mathrm{ABC}$ transporter and hypothetical proteins, which is flanked by transposases (LJ1292LJ1298). This cluster is absent in all other strains of $L$. johnsonii and L. gasseri analyzed to date. Taken together, these observations strongly argue for an horizontal gene transfer. Considering the marked conservation of this cluster compared to the rest of the L. taiwanensis genome, the hypothesis of its loss in the rest of the analysed strains is very unlikely.

In order to compare the genome conservation of L. taiwanensis BL263, L. gasseri ATCC $33323^{\mathrm{T}}$ and L. johnsonii ATCC $33200^{\mathrm{T}}$ versus L. johnsonii NCC533, their $\mathrm{CGH}$ results were combined in Fig. 6. Interestingly, variable or absent genes in L. taiwanensis and L. gasseri were not always shared by the two species. These "species-related" variable genes counted for almost one quarter of the L. johnsonii NCC533 genome. Since they were in minority related to mobile elements, this observation strongly supports three evolutionary branches. The number of genes conserved in L. taiwanensis and absent/divergent in L. gasseri was 257, whereas those conserved in L. gasseri and absent/divergent in L. taiwanensis were only 186 . These results clearly showed that L. taiwanensis is closer to L. johnsonii than L. gasseri is to L. johnsonii. The colour code of the Fig. 6 shows that most of the L. johnsonii ATCC $33200^{\mathrm{T}}$ absent/variable genes are also absent in the two other tested species. However, 63 genes absent in the L. johnsonii type strain are present in L. taiwanensis (Additional file 1). In contrast, a similar analysis performed with the CGH results of L. johnsonii BL261 instead of L. johnsonii ATCC $33200^{\mathrm{T}}$ retrieves only 34 genes absent in L. johnsonii BL261 and present in L. taiwanensis (Additional file 1). This difference may reflect the adaptation to different ecological niches, since $L$. johnsonii type strain have been isolated from human blood, whereas L. johnsonii strains NCC533 and BL261 and L. taiwanensis strain BL263 were isolated from intestinal content. Several genes conserved in L. taiwanensis BL263 and L. johnsonii BL261, but not in L. johnsonii ATCC $33200^{\mathrm{T}}$, would help to survival in such highly populated and competitive microbial environment. Among those genes are the bacteriocin lactacin F gene cluster, which is flanked by components of the L. johnsonii NCC533 mobilome, and 
Table 3 Differential phenotypic features of Lactobacillus taiwanensis strains (BL263, BL301, BL302, BL303, BL304) with respect to related species of the genus Lactobacillus (L. acidophilus, L. crispatus, L. gasseri, L. intestinalis, L. johnsonii, L. murinus and $L$. reuteri)

\begin{tabular}{|c|c|c|c|c|c|c|c|c|c|c|c|c|c|c|c|c|c|c|c|c|c|c|c|c|c|c|}
\hline Strains $^{a}$ & $\begin{array}{c}\text { BL } \\
263\end{array}$ & $\begin{array}{c}\mathrm{BL} \\
301 \\
\end{array}$ & $\begin{array}{c}\mathrm{BL} \\
302 \\
\end{array}$ & $\begin{array}{c}\mathrm{BL} \\
303\end{array}$ & $\begin{array}{c}\mathrm{BL} \\
304\end{array}$ & $\begin{array}{l}\mathrm{BL} \\
17 \\
\end{array}$ & $\begin{array}{c}\text { BL } \\
279 \\
\end{array}$ & $\begin{array}{c}\text { BL } \\
280 \\
\end{array}$ & $\begin{array}{c}\text { BL } \\
221\end{array}$ & $\begin{array}{c}\text { BL } \\
278 \\
\end{array}$ & $\begin{array}{c}\text { BL } \\
223\end{array}$ & $\begin{array}{ll}\text { BL } \\
277 \\
\end{array}$ & $\begin{array}{c}\text { BL } \\
292\end{array}$ & $\begin{array}{c}\text { BL } \\
294 \\
\end{array}$ & $\begin{array}{c}\text { BL } \\
296 \\
\end{array}$ & $\begin{array}{c}\text { BL } \\
260\end{array}$ & $\begin{array}{c}\mathrm{BL} \\
288\end{array}$ & $\begin{array}{c}\text { BL } \\
261\end{array}$ & $\begin{array}{c}\text { BL } \\
281 \\
\end{array}$ & $\begin{array}{c}\mathrm{BL} \\
287\end{array}$ & $\begin{array}{c}\mathrm{BL} \\
295\end{array}$ & $\begin{array}{c}\text { BL } \\
297\end{array}$ & $\begin{array}{c}\text { BL } \\
298\end{array}$ & $\begin{array}{c}\text { BL } \\
299 \\
\end{array}$ & $\begin{array}{c}\mathrm{BL} \\
262\end{array}$ & $\begin{array}{c}\mathrm{BL} \\
259 \\
\end{array}$ \\
\hline L-Arabinose & - & - & - & - & - & - & - & - & - & - & - & - & - & - & - & - & - & - & - & - & - & - & - & - & $d$ & $d$ \\
\hline Ribose & - & - & - & - & - & - & - & - & - & - & - & - & - & - & - & - & - & - & - & - & - & - & - & - & $d$ & $d$ \\
\hline D-Xylose & - & - & - & - & - & - & - & - & - & - & - & - & - & - & - & - & - & - & - & - & - & - & - & - & - & $d$ \\
\hline Galactose & - & - & - & - & $d$ & - & + & + & + & - & + & + & - & + & - & - & + & $d$ & $d$ & + & $d$ & - & - & $d$ & + & + \\
\hline D-Fructose & + & + & + & + & + & + & + & + & + & + & + & + & + & + & + & + & + & + & + & + & + & + & $d$ & + & + & - \\
\hline D-Mannose & + & + & + & + & + & + & + & + & $d$ & - & + & + & - & + & + & + & + & + & $d$ & + & + & + & $d$ & + & + & - \\
\hline Mannitol & - & - & - & - & - & - & - & - & + & - & - & - & - & - & - & $d$ & + & - & - & - & - & - & - & - & + & - \\
\hline $\begin{array}{l}\alpha \text {-methyl-D- } \\
\text { Glucoside }\end{array}$ & - & - & - & - & - & - & - & $d$ & $d$ & - & - & - & - & - & - & - & - & - & - & - & - & - & - & - & - & - \\
\hline $\begin{array}{l}\text { N-Acethyl } \\
\text { Glucosamine }\end{array}$ & - & $d$ & + & - & + & + & + & + & + & + & + & + & + & + & + & + & + & $d$ & $d$ & + & + & + & + & + & + & - \\
\hline Amygdalin & - & - & - & - & - & + & + & + & - & - & + & + & - & + & + & - & - & - & - & - & - & - & - & - & - & \\
\hline Arbutin & - & - & - & - & - & - & - & - & $d$ & + & + & + & + & - & + & - & - & - & - & - & - & - & - & - & + & - \\
\hline Aesculin & + & + & + & + & + & + & + & + & + & + & + & + & + & + & + & - & - & $d$ & - & + & + & + & + & + & + & - \\
\hline Salicin & - & - & - & - & - & + & + & $d$ & $d$ & + & + & + & $d$ & + & + & - & - & - & - & - & $d$ & $d$ & - & - & + & - \\
\hline Cellobiose & + & $d$ & + & + & + & + & + & $d$ & + & + & + & + & + & + & - & - & - & - & - & $d$ & $d$ & + & + & - & + & - \\
\hline Maltose & + & + & + & + & + & + & + & + & + & + & + & + & $d$ & + & + & + & + & + & + & + & + & + & - & + & + & + \\
\hline D-Lactose & - & - & - & - & - & + & + & + & + & - & + & + & - & + & - & - & - & - & - & $d$ & $d$ & + & + & - & + & + \\
\hline Melibiose & - & - & - & - & - & - & - & $d$ & - & - & - & - & - & - & - & - & - & - & - & - & - & - & - & - & + & + \\
\hline Trehalose & + & - & + & + & + & + & + & + & + & - & + & + & + & + & + & - & - & + & + & - & + & + & + & - & + & - \\
\hline D-Raffinose & - & - & - & - & - & $d$ & + & + & $d$ & - & - & - & - & - & - & - & $d$ & - & - & + & + & - & - & + & + & + \\
\hline Starch & - & - & - & - & - & - & - & - & + & + & + & + & - & - & - & - & - & $d$ & $d$ & $d$ & $d$ & $d$ & - & - & - & - \\
\hline Glycogen & - & - & - & - & - & - & - & - & + & + & - & - & - & - & - & - & - & - & - & - & - & - & - & - & - & - \\
\hline$\beta$-Gentibiose & $d$ & - & + & + & + & + & + & + & $d$ & - & + & + & + & + & + & - & - & + & - & + & + & + & - & + & + & - \\
\hline D-Turanose & - & - & - & - & - & - & - & - & - & - & + & - & - & - & - & - & - & - & - & - & - & - & - & - & $d$ & - \\
\hline D-Tagatose & - & - & - & - & - & - & - & - & - & - & + & + & $d$ & + & - & - & - & - & $d$ & $d$ & - & $d$ & - & - & - & - \\
\hline Growth $15^{\circ} \mathrm{C}$ & - & - & - & - & - & - & - & - & - & - & - & - & - & + & - & - & - & - & - & - & - & - & - & + & - & - \\
\hline Growth $45^{\circ} \mathrm{C}$ & - & - & - & - & - & - & - & - & - & - & - & + & - & + & + & - & - & - & - & - & - & + & + & + & - & - \\
\hline $\begin{array}{l}\text { Growth } 4.5 \% \\
\mathrm{NaCl}\end{array}$ & - & - & - & - & - & + & - & - & - & - & + & + & - & - & - & - & - & + & + & + & - & + & - & - & + & . \\
\hline $\begin{array}{l}\text { Growth } 7.0 \% \\
\mathrm{NaCl}\end{array}$ & - & - & - & - & - & - & - & - & - & + & + & - & - & - & - & - & - & - & - & - & - & - & - & - & - & \\
\hline Growth pH 4.5 & + & + & + & + & + & - & - & - & + & - & + & + & + & + & + & + & + & + & - & + & + & + & + & + & - & + \\
\hline
\end{tabular}

The strain names correspond with the list showed on Table 1. +, good growth; -, no growh; d, poor growth. All strains fermented D-glucose and sucrose. No strains fermented L-sorbose, rhamnose, inositol, sorbitol, inulin, melezitose, xylitol, fucose, arabitol or gluconate. 


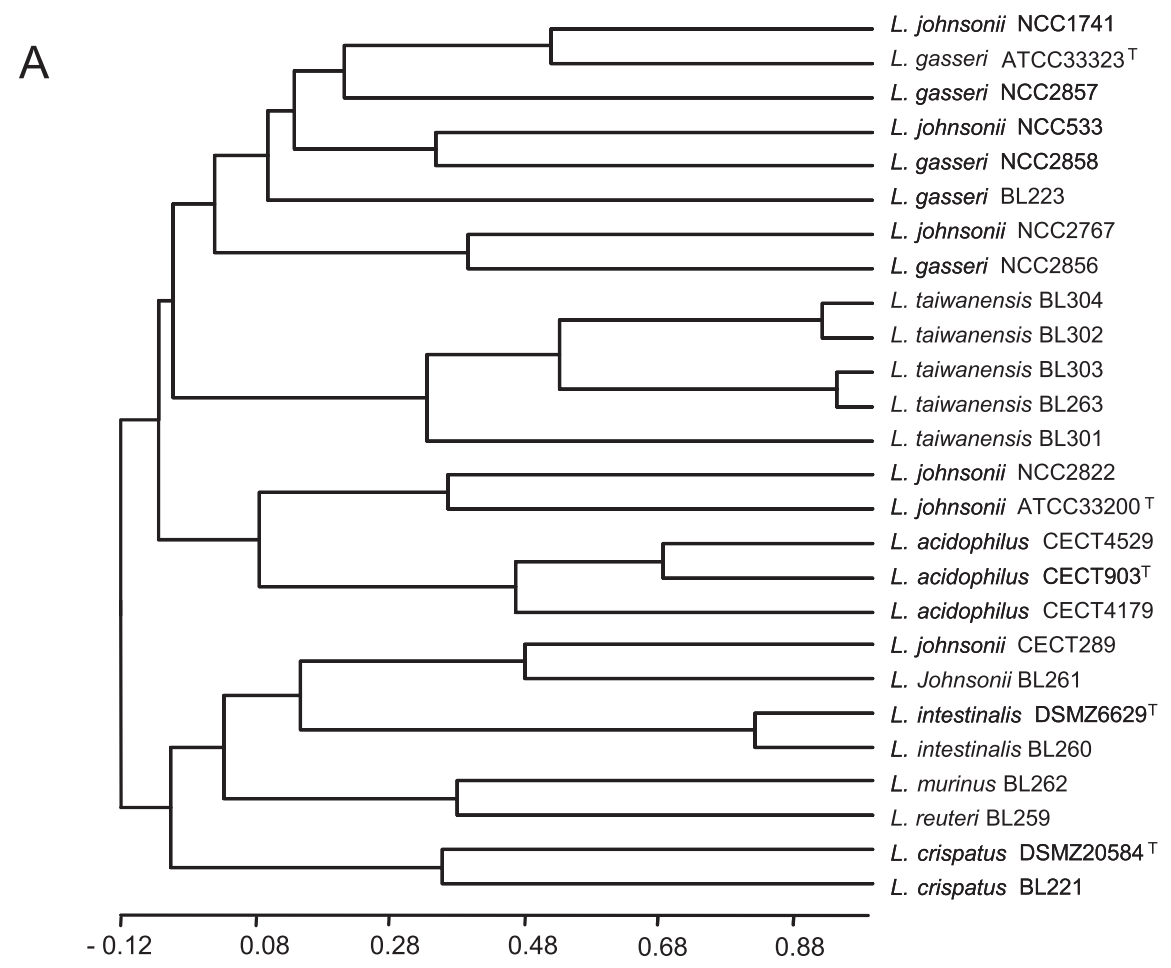

$\mathrm{B}$

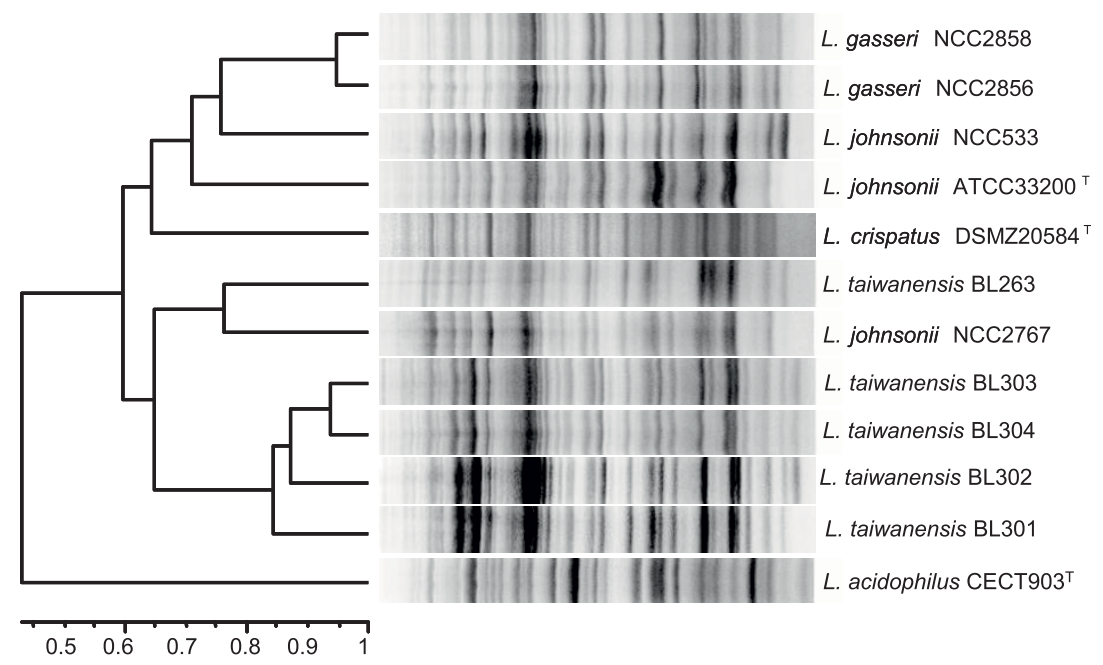

Figure 4 Dendrogram derived from the analysis of phenotypic properties (A) and SDS-PAGE whole-cell protein profiles (B) of Lactobacillus taiwanensis strains and related strains of species from the genus Lactobacillus. The analysis was performed using Pearson's correlation coefficient $(r)$ and the values are shown at the bottom of each dendrogram. Both trees (A and B) were constructed using the unweighted pair-group method with arithmetic averages (UPGMA).

genes encoding proteins hypothetically involved in transport and metabolism of carbohydrates (cellobiosespecific PTS, trehalose-specific PTS system).

\section{Discussion}

A previous study designed to analyze the prebiotic effect of sorbitol in a rat model, resulted in the isolation of five Lactobacillus strains from the intestinal content that could not be assigned conclusively to known species [29]. Here, we have shown that the five isolates share almost identical 16S rRNA gene sequences, they form a tight cluster in the recA, pheS, pyrG and tuf phylogenetic reconstructions and DNA-DNA hybridization experiments revealed close relatedness between them at 
Table 4 DNA re-association values as determined by DNA macroarray analysis among Lactobacillus strains

\begin{tabular}{|c|c|c|c|c|c|c|}
\hline & $\begin{array}{c}\text { L. intestinalis DSMZ } \\
6629^{\top}\end{array}$ & $\begin{array}{c}\text { L. johnsonii ATCC } \\
33200^{\top}\end{array}$ & $\begin{array}{l}\text { L. crispatus DSMZ } \\
20584^{\top}\end{array}$ & $\begin{array}{c}\text { L. gasseri ATCC } \\
33323^{\mathrm{T}}\end{array}$ & $\begin{array}{l}\text { L. acidophilus } \\
\text { CECT } 903^{\top}\end{array}$ & $\begin{array}{l}\text { L. taiwanensis } \\
\text { BL263 }\end{array}$ \\
\hline L. murinus BL262 & $1.95 \pm 1.39$ & $3.68 \pm 2.29$ & $2.41 \pm 0.83$ & $4.82 \pm 2.47$ & $1.23 \pm 0.07$ & $15.22 \pm 4.65$ \\
\hline L. reuteri BL259 & $4.33 \pm 4.16$ & $6.04 \pm 4.61$ & $3.87 \pm 4.17$ & $8.12 \pm 4.71$ & $5.93 \pm 2.16$ & $4.78 \pm 2.07$ \\
\hline $\begin{array}{l}\text { L. intestinalis DSMZ } \\
6629^{\top}\end{array}$ & 100.00 & $6.00 \pm 1.26$ & $3.66 \pm 1.10$ & $4.08 \pm 0.86$ & $6.79 \pm 2.11$ & $3.52 \pm 1.05$ \\
\hline L. intestinalis BL260 & $107.55 \pm 4.18$ & $9.90 \pm 3.70$ & $7.75 \pm 4.33$ & $9.93 \pm 4.83$ & $9.77 \pm 0.23$ & $7.27 \pm 1.86$ \\
\hline $\begin{array}{l}\text { L. johnsonii ATCC } \\
33200^{\top}\end{array}$ & $7.74 \pm 1.49$ & 100.00 & $5.15 \pm 0.70$ & $19.32 \pm 1.51$ & $7.57 \pm 1.73$ & $20.76 \pm 1.32$ \\
\hline $\begin{array}{l}\text { L. johnsonii CECT } \\
289\end{array}$ & $10.44 \pm 3.74$ & $81.91 \pm 8.39$ & $5.45 \pm 2.02$ & $23.12 \pm 7.98$ & $8.61 \pm 3.24$ & $28.28 \pm 6.53$ \\
\hline $\begin{array}{l}\text { L. johnsonii NCC } \\
2822\end{array}$ & $15.39 \pm 8.09$ & $94.25 \pm 12.15$ & $1.39 \pm 6.29$ & $45.64 \pm 4.48$ & $13.81 \pm 6.55$ & $35.37 \pm 11.93$ \\
\hline $\begin{array}{l}\text { L. johnsonii NCC } \\
1741\end{array}$ & $17.57 \pm 7.53$ & $91.82 \pm 8.88$ & $10.48 \pm 6.32$ & $38.06 \pm 8.11$ & $10.39 \pm 3.73$ & $35.18 \pm 9.31$ \\
\hline $\begin{array}{l}\text { L. johnsonii NCC } \\
533\end{array}$ & $9.70 \pm 5.52$ & $76.78 \pm 8.09$ & $9.73 \pm 7.20$ & $24.53 \pm 8.96$ & $8.31 \pm 3.82$ & $24.94 \pm 8.71$ \\
\hline $\begin{array}{l}\text { L. johnsonii NCC } \\
2767\end{array}$ & $16.00 \pm 7.28$ & $106.05 \pm 7.91$ & $13.33 \pm 8.54$ & $45.02 \pm 14.95$ & $11.35 \pm 3.62$ & $39.75 \pm 11.45$ \\
\hline L. johnsonii BL261 & $7.07 \pm 3.58$ & $56.49 \pm 8.70$ & $6.04 \pm 2.44$ & $19.74 \pm 3.73$ & $12.02 \pm 10.84$ & $24.15 \pm 2.27$ \\
\hline $\begin{array}{l}\text { L. crispatus DSMZ } \\
20584^{\top}\end{array}$ & $7.34 \pm 2.86$ & $6.22 \pm 1.06$ & 100.00 & $4.28 \pm 2.06$ & $11.70 \pm 5.35$ & $4.20 \pm 1.90$ \\
\hline L. crispatus BL221 & $7.14 \pm 2.66$ & $6.84 \pm 0.86$ & $82.06 \pm 10.06$ & $4.88 \pm 2.97$ & $8.40 \pm 2.87$ & $4.21 \pm 1.34$ \\
\hline $\begin{array}{l}\text { L. gasseri ATCC } \\
33323^{\top}\end{array}$ & $3.99 \pm 1.88$ & $15.62 \pm 2.19$ & $3.63 \pm 1.61$ & 100.00 & $3.25 \pm 0.77$ & $9.89 \pm 2.56$ \\
\hline L. gasseri NCC 2856 & $10.56 \pm 5.92$ & $31.63 \pm 9.46$ & $7.73 \pm 3.08$ & $76.31 \pm 6.36$ & $6.57 \pm 2.36$ & $21.74 \pm 6.62$ \\
\hline L. gasseri NCC 2857 & $11.54 \pm 6.36$ & $41.76 \pm 12.27$ & $11.11 \pm 6.48$ & $79.66 \pm 15.14$ & $8.73 \pm 3.21$ & $25.55 \pm 8.95$ \\
\hline L. gasseri NCC 2858 & $8.07 \pm 3.82$ & $29.36 \pm 9.15$ & $5.98 \pm 3.43$ & $71.09 \pm 5.46$ & $8.92 \pm 4.47$ & $19.56 \pm 5.14$ \\
\hline L. gasseri BL223 & $5.06 \pm 2.07$ & $21.28 \pm 1.75$ & $4.21 \pm 1.38$ & $62.11 \pm 9.80$ & $3.29 \pm 0.88$ & $14.13 \pm 2.67$ \\
\hline $\begin{array}{l}\text { L. acidophilus CECT } \\
903^{\top}\end{array}$ & $8.28 \pm 2.65$ & $7.06 \pm 0.08$ & $9.84 \pm 3.14$ & $6.18 \pm 2.42$ & 100.00 & $4.74 \pm 0.80$ \\
\hline $\begin{array}{l}\text { L. acidophilus CECT } \\
4529\end{array}$ & $8.59 \pm 3.38$ & $6.79 \pm 1.73$ & $9.08 \pm 3.40$ & $3.68 \pm 0.61$ & $98.60 \pm 6.52$ & $3.96 \pm 1.23$ \\
\hline $\begin{array}{l}\text { L. acidophilus CECT } \\
4179\end{array}$ & $7.10 \pm 3.61$ & $5.12 \pm 1.50$ & $6.72 \pm 2.72$ & $3.39 \pm 1.61$ & $101.10 \pm 2.45$ & $3.96 \pm 0.64$ \\
\hline $\begin{array}{l}\text { L. taiwanensis } \\
\text { BL263 }\end{array}$ & $7.50 \pm 1.18$ & $31.43 \pm 6.28$ & $6.98 \pm 2.42$ & $22.05 \pm 3.10$ & $6.19 \pm 1.73$ & 100.00 \\
\hline $\begin{array}{l}\text { L. taiwanensis } \\
\text { BL301 }\end{array}$ & $3.55 \pm 0.51$ & $18.20 \pm 5.85$ & $3.82 \pm 0.34$ & $12.61 \pm 2.42$ & $3.26 \pm 0.66$ & $72.61 \pm 10.45$ \\
\hline $\begin{array}{l}\text { L. taiwanensis } \\
\text { BL302 }\end{array}$ & $3.57 \pm 1.55$ & $19.56 \pm 4.20$ & $3.94 \pm 0.88$ & $13.18 \pm 0.71$ & $2.56 \pm 0.89$ & $94.95 \pm 5.69$ \\
\hline $\begin{array}{l}\text { L. taiwanensis } \\
\text { BL303 }\end{array}$ & $3.55 \pm 0.29$ & $17.65 \pm 6.63$ & $3.74 \pm 1.00$ & $12.96 \pm 2.37$ & $3.23 \pm 0.05$ & $86.54 \pm 8.38$ \\
\hline $\begin{array}{l}\text { L. taiwanensis } \\
\text { BL304 }\end{array}$ & $3.40 \pm 0.25$ & $17.31 \pm 6.16$ & $3.47 \pm 0.75$ & $12.73 \pm 2.10$ & $3.57 \pm 0.64$ & $75.04 \pm 8.82$ \\
\hline
\end{tabular}

Values were calculated as percentage of hybridization relative taking as a $100 \%$ the hybridization of each strain with itself and they are the means \pm SD from three independent hybridization experiments. Intra-specific DNA hybridization values are shown in bold.

the genomic level (> 72\%). They were therefore regarded to belong to the same species. During the preparation of this manuscript a new L. taiwanensis species isolated from silage was described [39]. 16S rRNA encoding gene and multilocus sequence analyses showed that our strains isolated from rat intestine belong to L. taiwanensis species. This species is placed within the L. acidophilus group, but they constituted a different cluster from their closest relatives, L. johnsonii and L. gasseri. The five L. taiwanensis strains have been isolated from the same environment and showed very high homology in the phylogenetic analyses; however, the carbohydrate utilization and growth profiles clearly distinguish $L$. taiwanensis BL301 from the groups made by L. taiwanensis strains BL304 and BL302 and by L. taiwanensis strains BL303 and BL263 (Table 3 and Fig. 1A). These two couples of strains can be distinguished by their protein profiles (Fig. 1B) and by DNA-DNA hybridization 
A
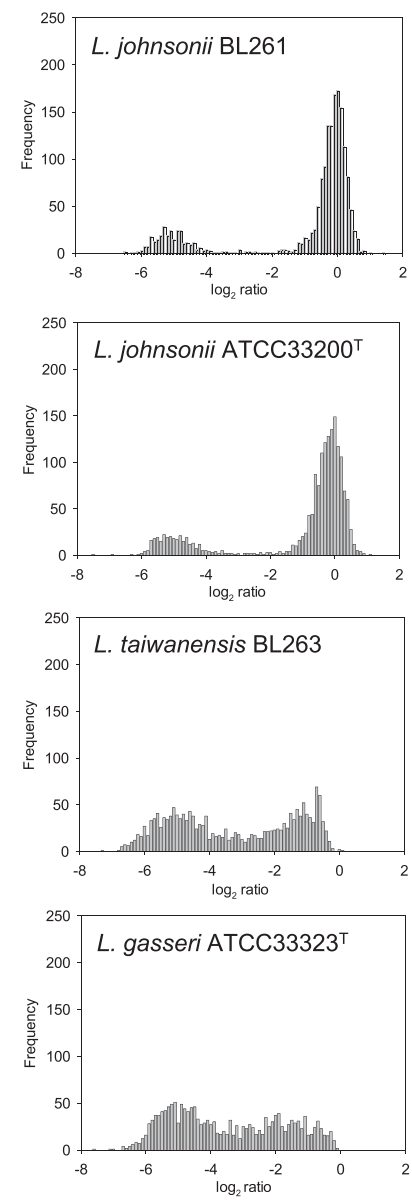

B

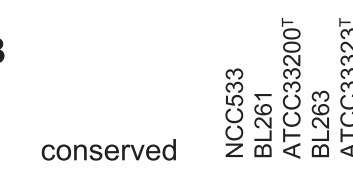

variable

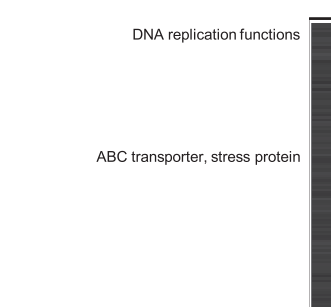

ribosomal proteins, translation functions

ribosomal proteins, transcription functions
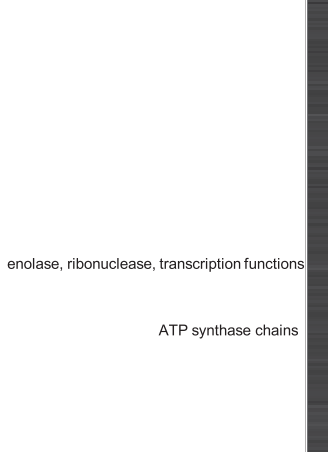

ribosomal proteins, HU protein
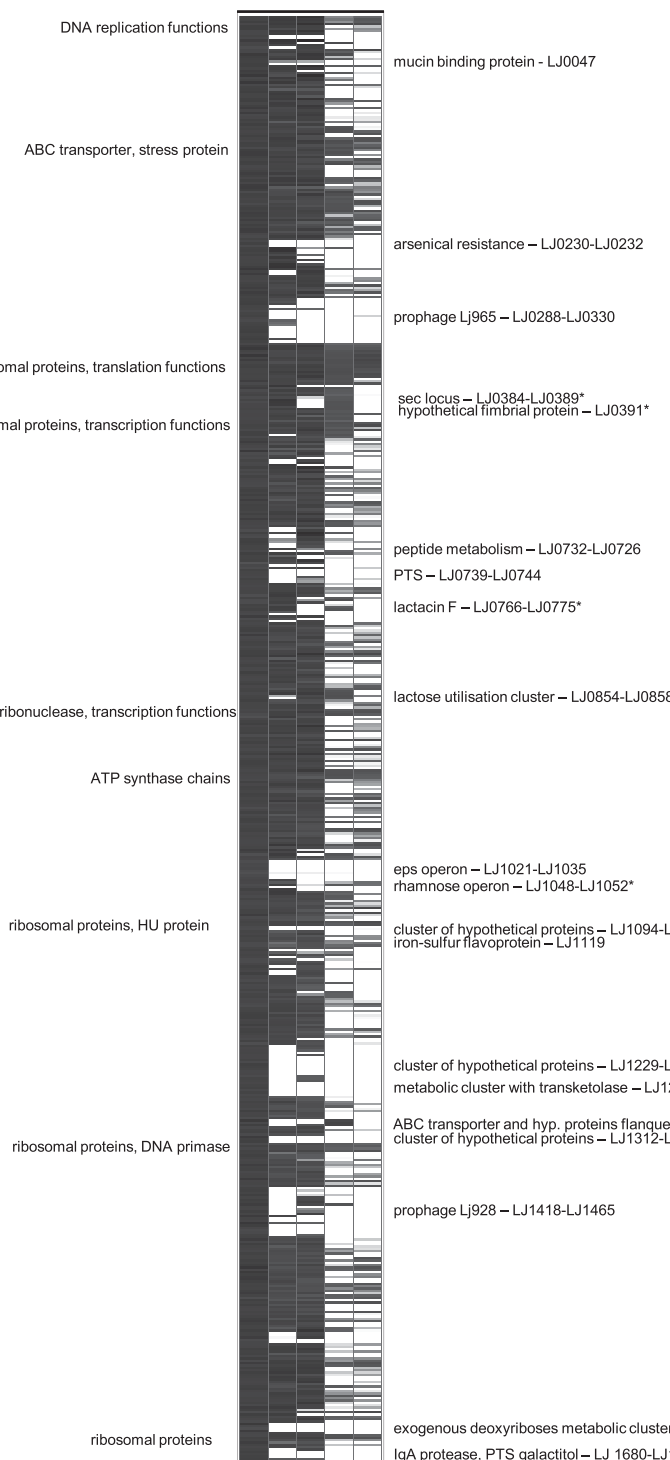

互

peptide metabolism - LJ0732-LJ0726

PTS - LJ0739-LJ0744

lactacin F- LJ0766-LJ0775*

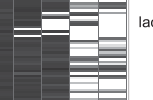

lactose utilisation cluster-LJ0854-LJ0858*

- 春

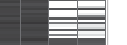

(1)

eps operon-LJ1021-LJ1035

eps operon - LJ1021-LJ1035
rhamnose operon - LJ1048-LJ1052*
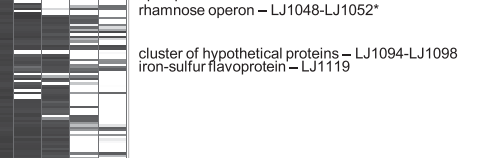

E $=\begin{aligned} & \text { cluster of hypothetical proteins - LJ1229-LJ1244 } \\ & \text { metabolic cluster with transketolase - LJ1257-1268 }\end{aligned}$

ABC transporter and hyp. proteins flanqued by transposases - LJ1292-LJ1298*

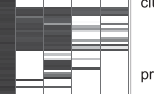

prophage Lj928 - LJ1418-LJ1465

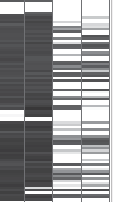

$\overline{\bar{\equiv}}$ exogenous deoxyriboses metabolic cluster - LJ1654-LJ1661

$=$ IgA protease, PTS galactitol - LJ 1680-LJ1683

=

ב- $=$ Potentially Autonomous Unit - LJ1749-LJ1745

$\mathrm{ABC}$ transporte

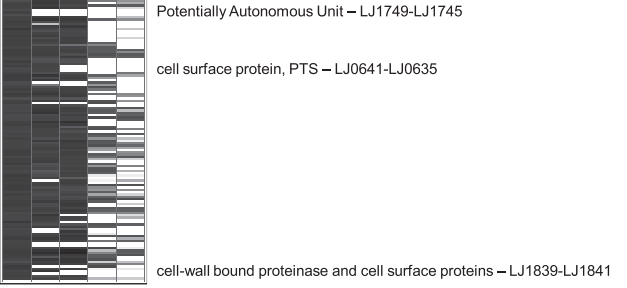

Figure 5 Comparative Genomic Hybridization (CGH) data. (A) Frequency distribution histograms of the CGH data. The reference strain is $L$. johnsonii NCC533. Ratios are expressed in a $\log _{2}$ scale; (B) CGH data mapped on L. johnsonii NCC533. Each horizontal row corresponds to a specific coding region on the array and the genes are vertically ordered according to their positions on the L. johnsonii NCC533 genome. The columns represent the strains analyzed, identified by their code numbers. The colour-code gradient ranges from black (presence of a homologous gene) to white (divergence or absence of a gene). Some relevant genes are shown on the left (conserved) or right (variable) alongside the genome. The asterisk showed conserved genes in L. taiwanensis, which are optional in L. johnsonii. 


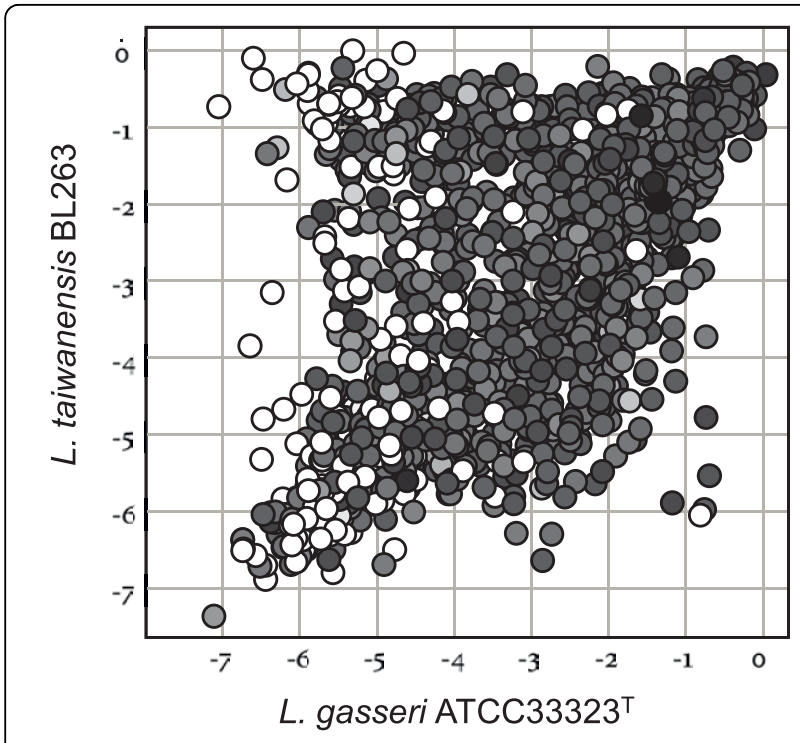

Figure 6 Genome conservation on L. johnsonii NCC533 microarrays. Scatter plot diagram of hybridization profiles for $L$. taiwanensis BL263 (y axis) versus L. gasseri ATCC $33323^{\top}$ ( $x$ axis). The axis values represent the hybridization signal ratios expressed in a $\log _{2}$ scale. For each gene, data points were colour-coded according to the hybridization profile of a third strain, $L$ johnsonii ATCC $33200^{\top}$. Gene conservation colour was obtained from the signal ratio for each gene in $\log _{2}$ scale. It ranged from black (presence in ATCC $32200^{\top}$ of a homologous gene with respect to the reference strain NCC533) to white (absence of a gene). For instance, a white circle in the top left corner of the plot represents a gene present in BL263 and absent in both ATCC $33323^{\top}$ and ATCC $32200^{\top}$.

experiments (Table 4). Taken together, these results indicate that the five L. taiwanensis isolates constitute distinct strains.

The microarray-based CGH has been used to characterize bacterial intra-species genetic diversity at the whole-genome level [41-46]. It has also been used for genome comparisons between species of the same genus or closely related genus that differ in environmental origin or virulence potential [47-49]. CGH analyses by microarrays have also been used to discriminate between the species of the L. acidophilus complex [26]. Here, microarray-based CGH technology has been applied to characterize a novel species by determining the gene by gene boundaries with its nearest phylogenetic neighbour. The rapid accumulation in the last years of complete genome bacterial sequences (at present there are 721 complete or in progress deposited genomes in the phylum Firmicutes, 57 of them of the genus Lactobacillus, at the National Center for Biotechnology Information), and the general trend towards an increase in genome sequencing projects will offer the opportunity of applying the DNA microarray-based CGH as an alternative to the classical whole genome DNA macroarray hybridizations for bacterial species determination. At a more affordable price than full genome sequencing, the CGH analysis renders many more information parameters than whole DNA re-association. Although the CGH microarrays presented the limitation of be unable to detect novel genes, it offers the re-association ratio for each ORF, the plot of the signal to ratio frequency, and the mapping of the conserved genes on the reference genome, thus providing a different ground for intra and inter-species comparisons. This work has shown that the inter-species profile comparison of the novel species L. taiwanensis clearly demonstrated its separate status respect to L. johnsonii.

The values obtained when comparing the relatedness of L. taiwanensis BL263 and L. johnsonii NCC533 using DNA-DNA hybridization with macro or microarrays may look dissimilar: whole DNA re-association values were $25 \%$ for the macroarray method, but in microarray CGH analysis $51 \%$ of the L. johnsonii NCC533 genes were conserved in L. taiwanensis. In this latter experiment, the hybridization ratios distribution of the conserved genes in L. taiwanensis is centred on -1 (Fig. $5 \mathrm{~A}$ ), which corresponds to a $50 \%$ reduced signal intensity. Therefore, $51 \%$ of conserved genes showing about $50 \%$ of signal intensity approximates $25 \%$ of global intensity, as observed by DNA-DNA hybridization.

A number of features on L. johnsonii NCC533 genome [13] that are conserved on L. taiwanensis BL263 may contribute to the adaptation of this bacterium to its ecological niche. Interestingly, our combined CGH results with two L. johnsonii strains showed that $L$. taiwanensis BL263 is closer to the gut isolate L. johnsonii BL261 than to the blood isolate L. johnsonii ATCC $33200^{\mathrm{T}}$. The L. johnsonii NCC533 genome encodes 16 putative phosphoenolpyruvate: sugar phosphotransferase systems (PTSs) and several of them, including the ones annotated for fructose, glucose and cellobiose transport, are specifically induced in the gastrointestinal tract (GIT) [14]. CGH results showed that four PTSs, hypothetically involved in transport and metabolism of fructose, cellobiose, trehalose and sucrose are conserved in L. taiwanensis BL263. These predictions are supported by the API $50 \mathrm{CH}$ results showed for L. taiwanensis BL263 (Table 3). A putative maltose/maltodextrin utilization gene cluster, which includes a gene coding for a putative neopullulanase/maltogenic $\alpha$-amylase, is conserved in $L$. taiwanensis BL263, suggesting that this strain may use starch-degraded products. Other enzymes that may contribute to the survival/persistence of L. taiwanensis BL263 in the GIT are bile salt hydrolases (BSH). These enzymes have been almost exclusively found in bacterial species associated with the GIT and its role has been largely discussed [see review [50]. L. taiwanensis BL263 exhibited taurocholic and taurodeoxycholic acid deconjugation activity (L. A. Sarmiento-Rubiano and M. J. Yebra, unpublished results). This is in agreement with 
the CGH analysis showing that a putative operon encoding a BSH and two bile salt transporters (LJ0056 to LJ0058) on L. johnsonii NCC533 genome is conserved in L. taiwanensis BL263, although this strain has only one of the two transporter encoding genes. Homologues of these genes in L. johnsonii 100-100 were shown to be gene duplicates and to have a function in taurocholic acid uptake [51,52]. The ability of L. johnsonii NCC533 to interact with mucins and epithelial cells has been shown to likely rely on cell-surface associated elongation factor $\mathrm{Tu}$ and heat shock protein GroEL [53,54]. As expected for these classes of proteins, their encoding genes (LJ1009 and LJ0461) are also conserved on L. taiwanensis BL263, offering a putative role of the encoded proteins in the interaction of this strain with the host. This interaction may also be influenced by the presence of another conserved gene encoding a putative adhesin (LJ0391) that showed similarities with Fap1 fimbrial protein from Streptococcus parasanguinis [55].

Previous studies using DNA microarray-based CGH and in silico comparative genomic analysis showed a wide sequence similarity and an accurate genome synteny between $L$. johnsonii and L. gasseri species [13,26]. In spite of this tight relationship, the novel Lactobacillus species described here is placed in a third branching of similar closeness, which raised once more the question about the limits of species delineation. Additionally, the CGH analysis showed that the new species is genetically slightly closer to L. johnsonii than L. gasseri is. This result is also supported by our DNA-DNA hybridization data and our phylogenetic analysis of recA, pheS, pyrG and $t u f$ sequences in these three species.

\section{Conclusion}

Since the genome is the final target of all the molecular taxonomic indicators of species determination, the DNA microarray-based CGH analysis is the most powerful technology for strain typing and species assignment, just behind the costly genome sequencing. In this work we have characterized with conventional taxonomic analyses a novel Lactobacillus species within the L. acidophilus group, and with microarray-based CGH analysis we confirmed the status of L. taiwanensis BL263 as species showing gene by gene differences and similarities with its closest relative L. johnsonii strain NCC533.

\section{Additional material}

Additional file 1: Genes on L. johnsonii NCC533 that are conserved on $L$. taiwanensis BL263 but not in L. johnsonii ATCC $33200^{\top}$ or $L$. johnsonii BL261. This table contains 63 and 34 genes on L. johnsonii NCC533 that are conserved on L. taiwanensis BL263 and absence on L. johnsonii type strain or L. johnsonii BL261, respectively.

\section{Acknowledgements}

This work was financed by funds of the Project AGL2004-03886 and Consolider Fun-c-Food CSD2007-00063 from the Spanish Ministry of Science and Innovation. We thank Fabienne Praplan for sharing and discussing unpublished results of proteomics.

\section{Author details}

${ }^{1}$ Laboratorio de Bacterias Lácticas y Probióticos. IATA-CSIC, P.O. Box 73, 46100 Burjassot, Valencia, Spain. ${ }^{2}$ Nestlé Research Center, CH-1000 Lausanne 26, Vers-chez-les-Blanc, Switzerland.

\section{Authors' contributions}

LASR has isolated the five strains of the L. taiwanensis species and performed all the experiments related to conventional taxonomic analyses. BB designed and analyzed the microarray-based CGH experiments. DM performed the microarray-based CGH experiments. MZ designed and performed the phylogenetic analyses. GPM and MJY designed the study and supervised it. MJY drafted the manuscript. LSAR, BB, MZ and GPM helped improving the draft. All authors read and approved the final manuscript.

\section{Competing interests}

The authors declare that they have no competing interests.

Received: 4 February 2010 Accepted: 17 September 2010 Published: 17 September 2010

\section{References}

1. Sazawal S, Hiremath G, Dhingra U, Malik P, Deb S, Black RE: Efficacy of probiotics in prevention of acute diarrhoea: a meta-analysis of masked, randomised, placebo-controlled trials. Lancet Infect Dis 2006, 6(6):374-382.

2. Sheil B, Shanahan F, O'Mahony L: Probiotic effects on inflammatory bowel disease. J Nutr 2007, 137(3 Suppl 2):819S-824S.

3. de Vrese M, Marteau PR: Probiotics and prebiotics: effects on diarrhea. J Nutr 2007, 137(3 Suppl 2):803S-811S.

4. Johnson JL, Phelps CF, Cummins CS, London J, Gasser F: Taxonomy of the Lactobacillus acidophilus group. Int J Syst Bacteriol 1980, 30:53-68.

5. Fujisawa T, Benno Y, Yaeshima T, Mitsuoka T: Taxonomic study of the Lactobacillus acidophilus group, with recognition of Lactobacillus gallinarum sp. nov. and Lactobacillus johnsonii sp. nov. and synonymy of Lactobacillus acidophilus group A3 (Johnson et al. 1980) with the type strain of Lactobacillus amylovorus (Nakamura 1981). Int J Syst Bacteriol 1992, 42(3):487-491.

6. Zhang W, Azevedo MS, Wen K, Gonzalez A, Saif LJ, Li G, Yousef AE, Yuan L: Probiotic Lactobacillus acidophilus enhances the immunogenicity of an oral rotavirus vaccine in gnotobiotic pigs. Vaccine 2008, 26(2930):3655-3661.

7. Candela M, Perna F, Carnevali P, Vitali B, Ciati R, Gionchetti P, Rizzello F, Campieri M, Brigidi P: Interaction of probiotic Lactobacillus and Bifidobacterium strains with human intestinal epithelial cells: adhesion properties, competition against enteropathogens and modulation of IL-8 production. Int J Food Microbiol 2008, 125(3):286-292.

8. Inoue R, Otsuka M, Nishio A, Ushida K: Primary administration of Lactobacillus johnsonii NCC533 in weaning period suppresses the elevation of proinflammatory cytokines and CD86 gene expressions in skin lesions in NC/Nga mice. FEMS Immunol Med Microbiol 2007, 50(1):67-76

9. Tanaka A, Fukushima Y, Benyacoub J, Blum S, Matsuda H: Prophylactic effect of oral administration of Lactobacillus johnsonii NCC533 (La1) during the weaning period on atopic dermatitis in NC/NgaTnd mice. Eur J Dermatol 2008, 18(2):136-140.

10. Fukushima $Y$, Miyaguchi S, Yamano T, Kaburagi T, lino H, Ushida K, Sato K: Improvement of nutritional status and incidence of infection in hospitalised, enterally fed elderly by feeding of fermented milk containing probiotic Lactobacillus johnsonii La1 (NCC533). Br J Nutr 2007, 98(5):969-977

11. Haller D, Blum S, Bode C, Hammes WP, Schiffrin EJ: Activation of human peripheral blood mononuclear cells by nonpathogenic bacteria in vitro: evidence of NK cells as primary targets. Infect Immun 2000, 68(2):752-759.

12. Ibnou-Zekri N, Blum S, Schiffrin EJ, von der Weid T: Divergent patterns of colonization and immune response elicited from two intestinal 
Lactobacillus strains that display similar properties in vitro. Infect Immun 2003, 71(1):428-436.

13. Pridmore RD, Berger $B$, Desiere F, Vilanova D, Barretto C, Pittet AC, Zwahlen MC, Rouvet M, Altermann E, Barrangou R, Mollet B, Mercenier A, Klaenhammer T, Arigoni F, Schell MA: The genome sequence of the probiotic intestinal bacterium Lactobacillus johnsonii NCC 533. Proc Natl Acad Sci USA 2004, 101(8):2512-2517.

14. Denou E, Berger B, Barretto C, Panoff JM, Arigoni F, Brussow H: Gene expression of commensal Lactobacillus johnsonii strain NCC533 during in vitro growth and in the murine gut. J Bacteriol 2007, 189(22):8109-8119

15. Denou E, Pridmore RD, Berger B, Panoff JM, Arigoni F, Brussow H: Identification of genes associated with the long-gut-persistence phenotype of the probiotic Lactobacillus johnsonii strain NCC533 using a combination of genomics and transcriptome analysis. J Bacteriol 2008, 190(9):3161-3168.

16. Riley MA, Lizotte-Waniewski M: Population genomics and the bacterial species concept. Methods Mol Biol 2009, 532:367-377.

17. Fraser C, Hanage WP, Spratt BG: Recombination and the nature of bacterial speciation. Science 2007, 315(5811):476-480.

18. Lan R, Reeves PR: Gene transfer is a major factor in bacterial evolution. Mol Biol Evol 1996, 13(1):47-55.

19. Stackebrandt E, Frederiksen W, Garrity GM, Grimont PA, Kampfer P, Maiden MC, Nesme X, Rossello-Mora R, Swings J, Truper HG, Vauterin L, Ward AC, Whitman WB: Report of the ad hoc committee for the reevaluation of the species definition in bacteriology. Int I Syst Evol Microbiol 2002, 52(Pt 3):1043-1047.

20. Rossello-Mora R, Amann R: The species concept for prokaryotes. FEMS Microbiol Rev 2001, 25(1):39-67.

21. Pot B, Hertel C, Ludwig W, Descheemaeker P, Kersters K, Schleifer KH: Identification and classification of Lactobacillus acidophilus, L. gasseri and $L$. johnsonii strains by SDS-PAGE and rRNA-targeted oligonucleotide probe hybridization. J Gen Microbiol 1993, 139(3):513-517.

22. Du Plessis EM, Dicks LM: Evaluation of random amplified polymorphic DNA (RAPD)-PCR as a method to differentiate Lactobacillus acidophilus, Lactobacillus crispatus, Lactobacillus amylovorus, Lactobacillus gallinarum, Lactobacillus gasseri, and Lactobacillus johnsonii. Curr Microbiol 1995, 31(2):114-118

23. Roy D, Ward P, Vincent D, Mondou F: Molecular identification of potentially probiotic lactobacilli. Curr Microbiol 2000, 40(1):40-46

24. Kullen MJ, Sanozky-Dawes RB, Crowell DC, Klaenhammer TR: Use of the DNA sequence of variable regions of the 16S rRNA gene for rapid and accurate identification of bacteria in the Lactobacillus acidophilus complex. J Appl Microbiol 2000, 89(3):511-516.

25. Ryu CS, Czajka JW, Sakamoto M, Benno Y: Characterization of the Lactobacillus casei group and the Lactobacillus acidophilus group by automated ribotyping. Microbiol Immunol 2001, 45(4):271-275.

26. Berger B, Pridmore RD, Barretto C, Delmas-Julien F, Schreiber K, Arigoni F, Brussow H: Similarity and differences in the Lactobacillus acidophilus group identified by polyphasic analysis and comparative genomics. J Bacteriol 2007, 189(4):1311-1321.

27. Ventura M, Canchaya C, Pridmore D, Berger B, Brussow H: Integration and distribution of Lactobacillus johnsonii prophages. J Bacteriol 2003, 185(15):4603-4608.

28. Ventura M, Canchaya C, Pridmore RD, Brussow H: The prophages of Lactobacillus johnsonii NCC 533: comparative genomics and transcription analysis. Virology 2004, 320(2):229-242.

29. Sarmiento-Rubiano LA, Zuniga M, Perez-Martinez G, Yebra MJ: Dietary supplementation with sorbitol results in selective enrichment of lactobacilli in rat intestine. Res Microbiol 2007, 158(8-9):694-701.

30. Posno M, Leer RJ, van Luijk N, van Giezen MJ, Heuvelmans PT, Lokman BC, Pouwels PH: Incompatibility of Lactobacillus Vectors with Replicons Derived from Small Cryptic Lactobacillus Plasmids and Segregational Instability of the Introduced Vectors. Appl Environ Microbiol 1991, 57(6):1822-1828

31. Diancourt L, Passet V, Chervaux C, Garault P, Smokvina T, Brisse S: Multilocus sequence typing of Lactobacillus casei reveals a clonal population structure with low levels of homologous recombination. App/ Environ Microbiol 2007, 73(20):6601-6611.

32. Cole JR, Chai B, Farris RJ, Wang Q, Kulam SA, McGarrell DM, Garrity GM, Tiedje JM: The Ribosomal Database Project (RDP-II): sequences and tools for high-throughput rRNA analysis. Nucleic Acids Res 2005, 33 Database: D294-296.

33. Aiyar A: The use of CLUSTAL W and CLUSTAL X for multiple sequence alignment. Methods Mol Biol 2000, 132:221-241.

34. Castresana J: Selection of conserved blocks from multiple alignments for their use in phylogenetic analysis. Mol Biol Evol 2000, 17(4):540-552.

35. Guindon S, Lethiec F, Duroux P, Gascuel O: PHYML Online-a web server for fast maximum likelihood-based phylogenetic inference. Nucleic Acids Res 2005, 33 Web Server: W557-559.

36. Sambrook J, Fritsch EF, Maniatis T, (eds): Molecular cloning: a laboratory manual. Cold Spring Harbor, NY: Cold Spring Harbor Laboratory 1989.

37. Hanninen ML, Happonen I, Saari S, Jalava K: Culture and characteristics of Helicobacter bizzozeronii, a new canine gastric Helicobacter sp. Int J Syst Bacteriol 1996, 46(1):160-166.

38. Edgar R, Domrachev M, Lash AE: Gene Expression Omnibus: NCBI gene expression and hybridization array data repository. Nucleic Acids Res 2002, 30(1):207-210.

39. Wang LT, Kuo HP, Wu YC, Tai CJ, Lee FL: Lactobacillus taiwanensis sp. nov., isolated from silage. Int J Syst Evol Microbiol 2009, 59(Pt 8):2064-2068.

40. Dellaglio F, Felis GE: Taxonomy of lactobacillus and bifidobacteria. In Probiotics and prebiotics: scientific aspects. Edited by: Tannock GW. Wymondham, Norfolk, United Kingdom: Caister Academic Press; 2005:25-49.

41. King AJ, an Gorkom T, Pennings J L, van der Heide HG, He Q, Diavatopoulos D, Heuvelman K, van Gent M, van Leeuwen K, Mooi FR: Comparative genomic profiling of Dutch clinical Bordetella pertussis isolates using DNA microarrays: identification of genes absent from epidemic strains. BMC Genomics 2008, 9:311.

42. McLeod A, Nyquist OL, Snipen L, Naterstad K, Axelsson L: Diversity of Lactobacillus sakei strains investigated by phenotypic and genotypic methods. Syst Appl Microbiol 2008, 31(5):393-403.

43. Molenaar D, Bringel F, Schuren FH, de Vos WM, Siezen RJ, Kleerebezem M: Exploring Lactobacillus plantarum genome diversity by using microarrays. J Bacteriol 2005, 187(17):6119-6127.

44. Pang B, Yan M, Cui Z, Ye X, Diao B, Ren Y, Gao S, Zhang L, Kan B: Genetic diversity of toxigenic and nontoxigenic Vibrio cholerae serogroups $\mathrm{O} 1$ and 0139 revealed by array-based comparative genomic hybridization. $J$ Bacteriol 2007, 189(13):4837-4849.

45. Paustian ML, Zhu X, Sreevatsan S, Robbe-Austerman S, Kapur V, Bannantine JP: Comparative genomic analysis of Mycobacterium avium subspecies obtained from multiple host species. BMC Genomics 2008, 9:135.

46. Rasmussen TB, Danielsen M, Valina O, Garrigues C, Johansen E, Pedersen MB: Streptococcus thermophilus core genome: comparative genome hybridization study of 47 strains. Appl Environ Microbiol 2008, 74(15):4703-4710.

47. Chan K, Baker S, Kim CC, Detweiler CS, Dougan G, Falkow S: Genomic comparison of Salmonella enterica serovars and Salmonella bongori by use of an S. enterica serovar typhimurium DNA microarray. J Bacteriol 2003, 185(2):553-563.

48. Fukiya S, Mizoguchi $\mathrm{H}$, Tobe T, Mori $\mathrm{H}$ : Extensive genomic diversity in pathogenic Escherichia coli and Shigella Strains revealed by comparative genomic hybridization microarray. J Bacteriol 2004, 186(12):3911-3921.

49. Ong C, Ooi CH, Wang D, Chong H, Ng KC, Rodrigues F, Lee MA, Tan P: Patterns of large-scale genomic variation in virulent and avirulent Burkholderia species. Genome Res 2004, 14(11):2295-2307.

50. Begley M, Hill C, Gahan CG: Bile salt hydrolase activity in probiotics. Appl Environ Microbiol 2006, 72(3):1729-1738.

51. Elkins CA, Moser SA, Savage DC: Genes encoding bile salt hydrolases and conjugated bile salt transporters in Lactobacillus johnsonii 100-100 and other Lactobacillus species. Microbiology 2001, 147(Pt 12):3403-3412.

52. Elkins CA, Savage DC: Identification of genes encoding conjugated bile salt hydrolase and transport in Lactobacillus johnsonii 100-100. $J$ Bacteriol 1998, 180(17):4344-4349.

53. Bergonzelli GE, Granato D, Pridmore RD, Marvin-Guy LF, Donnicola D, Corthesy-Theulaz IE: GroEL of Lactobacillus johnsonii La1 (NCC 533) is cell surface associated: potential role in interactions with the host and the gastric pathogen Helicobacter pylori. Infect Immun 2006, 74(1):425-434.

54. Granato D, Bergonzelli GE, Pridmore RD, Marvin L, Rouvet M, CorthesyTheulaz IE: Cell surface-associated elongation factor Tu mediates the 
attachment of Lactobacillus johnsonii NCC533 (La1) to human intestinal cells and mucins. Infect Immun 2004, 72(4):2160-2169.

55. Wu H, Zeng M, Fives-Taylor P: The glycan moieties and the N-terminal polypeptide backbone of a fimbria-associated adhesin, Fap1, play distinct roles in the biofilm development of Streptococcus parasanguinis. Infect Immun 2007, 75(5):2181-2188.

doi:10.1186/1471-2164-11-504

Cite this article as: Sarmiento-Rubiano et al: Characterization of a novel Lactobacillus species closely related to Lactobacillus johnsonii using a combination of molecular and comparative genomics methods. BMC Genomics 2010 11:504.

Submit your next manuscript to BioMed Central and take full advantage of:

- Convenient online submission

- Thorough peer review

- No space constraints or color figure charges

- Immediate publication on acceptance

- Inclusion in PubMed, CAS, Scopus and Google Scholar

- Research which is freely available for redistribution

Submit your manuscript at www.biomedcentral.com/submit
C Biomed Central 